\title{
Impact of weight loss diet associated with flaxseed on inflammatory markers in men with cardiovascular risk factors: a clinical study
}

Roberta Soares Lara Cassani ${ }^{1}$, Priscila Giacomo Fassini ${ }^{2 *}$, Jose Henrique Silvah ${ }^{2}$, Cristiane Maria Mártires Lima ${ }^{2}$ and Júlio Sérgio Marchini ${ }^{2}$

\begin{abstract}
Background: Flaxseed has received attention for its anti-inflammatory and antioxidant role. The present study hypothesizes if flaxseed added to a weight loss diet could improve the lipid and metabolic profiles and decrease risk factors related to cardiovascular disease.

Methods: In a prospective, single blinded 42 days protocol, subjects were allocated into two groups with low carbohydrates intake: $G_{\text {ricelC }}$ (35\% of carbohydrate and $60 \mathrm{~g}$ of raw rice powder per day) and $G_{\text {flaxLC }}$ (32\% of carbohydrate and $60 \mathrm{~g}$ of flaxseed powder per day). Blood pressure, anthropometric measures and serum levels of isoprostane, C-reactive protein, Tumor Necrosis Factor-alpha, glucose, lipidic profile, uric acid, adiponectin, leptin and insulin were measured at baseline and at the end of interventions. Serum and urinary enterodiol and enterolactione were also measured.

Results: A total of 27 men with cardiovascular risk factors were evaluated, with mean age of $33 \pm 10$ years to $G_{\text {ricelc }}$ and $40 \pm 9$ years to $G_{\text {flaxLC. }}$. Both groups experienced weight loss and systolic blood pressure reduction. A decrease in inflammatory markers (CRP and TNF-a) was observed after flaxseed intake (mean decrease of 25\% and $46 \%$ for $G_{\text {flaxLC }}$ respectively). All groups also showed improvement in levels of total cholesterol, LDL-C, uric acid and adiponectin. Only $G_{\text {flaxLC }}$ group showed a decrease in triglyceride levels.
\end{abstract}

Conclusion: This study suggests that flaxseed added to a weight loss diet could be an important nutritional strategy to reduce inflammation markers such as CRP and TNF-a.

Trial registration: ClinicalTrials.gov NCT02132728.

Keywords: Flaxseed, Inflammation, Weight loss, Obesity

\section{Background}

Obesity is associated with altered inflammatory markers such as high blood levels of C-Reactive Protein (CRP) and Tumor Necrosis Factor-alpha (TNF- $\alpha)[1,2]$ and reduced of adiponectin $[3,4]$. This can contribute to incidence of diseases once adiponectin, in high levels, has been associated with a lower risk of cardiovascular death $[5,6]$.

\footnotetext{
* Correspondence: priscilafassini@usp.br

${ }^{2}$ Department of Medicine, Division of Medical Nutrition, Ribeirão Preto Medical School, University of São Paulo, Avenida Bandeirantes, 3900 Bairro Monte Alegre, CEP: 14049-900, Ribeirão Preto, São Paulo, Brazil

Full list of author information is available at the end of the article
}

The most common approach for treatment of obesity includes hypocaloric diets resulting in energy deficit associated with restriction of certain food groups, such as those containing high-carbohydrate [7].

Additionally,a recent literature review indicates more than 1000 weight loss diets published. While some eliminate one or more groups of food, others recommend the intake of specific food, based on different effects on the metabolism [8]. Thus, by adding or removing a certain food seems to be possible that weight loss diets manage inflammation, as a modifiable risk factor [9-11].

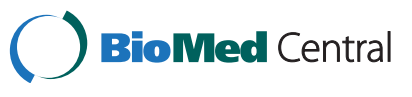


Table 1 Nutritional composition of diet according to 24-hours food recall in both groups and times assessed

\begin{tabular}{|c|c|c|c|}
\hline \multirow[t]{2}{*}{ Variable } & \multirow[t]{2}{*}{ Time } & \multicolumn{2}{|c|}{ Group } \\
\hline & & $G_{\text {ricelC }}(n=13)$ & $\mathrm{G}_{\mathrm{flaxLC}}(\mathrm{n}=14)$ \\
\hline \multirow[t]{3}{*}{ Energy (kcal/day) } & Initial & $3869 \pm 1012^{* a}$ & $3665 \pm 713^{* a}$ \\
\hline & Final & $1765 \pm 193$ & $1578 \pm 213$ \\
\hline & Mean difference & $-2104 \pm 997$ & $-2154 \pm 738$ \\
\hline \multirow[t]{3}{*}{ Carbohydrate (g/d) } & Initial & $451 \pm 118^{* a}$ & $478 \pm 73^{* a}$ \\
\hline & Final & $201 \pm 32$ & $159 \pm 28$ \\
\hline & Mean difference & $-188 \pm 214$ & $-318 \pm 76$ \\
\hline \multirow[t]{3}{*}{ Protein (g/d) } & Initial & $187 \pm 53^{* a}$ & $152 \pm 55^{* a}$ \\
\hline & Final & $122 \pm 22$ & $118 \pm 23$ \\
\hline & Mean difference & $-65 \pm 59$ & $-34 \pm 57$ \\
\hline \multirow[t]{3}{*}{ Fat $(\mathrm{g} / \mathrm{d})$} & Initial & $135 \pm 62^{* a}$ & $127 \pm 37^{* a}$ \\
\hline & Final & $54 \pm 15$ & $55 \pm 11$ \\
\hline & Mean difference & $-81 \pm 71$ & $-75 \pm 37$ \\
\hline \multirow[t]{3}{*}{ MUFA (g/d) } & Initial & $43 \pm 20^{* a}$ & $42 \pm 12^{* a}$ \\
\hline & Final & $26 \pm 9$ & $19 \pm 6$ \\
\hline & Mean difference & $-17 \pm 26$ & $-20 \pm 17$ \\
\hline \multirow[t]{3}{*}{ PUFA (g/d) } & Initial & $25 \pm 13^{* a}$ & $24 \pm 9$ \\
\hline & Final & $12 \pm 6$ & $24 \pm 5$ \\
\hline & Mean difference & $-6 \pm 14$ & $-0.8 \pm 10$ \\
\hline \multirow[t]{3}{*}{$\omega-3(g / d)$} & Initial & $3 \pm 2$ & $4 \pm 3^{*} a$ \\
\hline & Final & $3 \pm 2$ & $14 \pm 2$ \\
\hline & Mean difference & $-0.3 \pm 2.5$ & $10 \pm 3^{* * b}$ \\
\hline \multirow[t]{3}{*}{$\omega-6(g / d)$} & Initial & $22 \pm 11^{* a}$ & $22 \pm 8^{* a}$ \\
\hline & Final & $9 \pm 5$ & $10 \pm 4$ \\
\hline & Mean difference & $-13 \pm 13$ & $-12 \pm 9$ \\
\hline \multirow[t]{3}{*}{ SFA $(g / d)$} & Initial & $51 \pm 27^{* a}$ & $51 \pm 16^{* a}$ \\
\hline & Final & $13 \pm 3$ & $12 \pm 3$ \\
\hline & Mean difference & $-35 \pm 32$ & $-38 \pm 14$ \\
\hline \multirow[t]{3}{*}{ Dietary cholesterol (mg/d) } & Initial & $569 \pm 220^{* a}$ & $583 \pm 313^{* a}$ \\
\hline & Final & $267 \pm 67$ & $248 \pm 59$ \\
\hline & Mean difference & $-334 \pm 254$ & $-335 \pm 322$ \\
\hline \multirow[t]{3}{*}{ Total fiber (g/d) } & Initial & $41 \pm 15^{* a}$ & $42 \pm 14$ \\
\hline & Final & $26 \pm 6$ & $41 \pm 5$ \\
\hline & Mean difference & $-15 \pm 15$ & $-7 \pm 20$ \\
\hline
\end{tabular}

Data are expressed in mean \pm Standard Deviation. $n$, number of subjects; Kcal/day, kilocalorie per day; $\mathrm{g} / \mathrm{d}$, grams per day; $\mathrm{mg} / \mathrm{d}$, milligrams per day; SFA, saturated fatty acids; MUFA, monounsaturated fatty acids; PUFA, polyunsaturated fatty acids $\omega-3$, omega 3 fatty acids, $\omega-6$, omega 6 fatty acids. **Significant difference between initial and final times $(p<0.01)$.

${ }^{a}$ Mean-comparison $t$ test, paired data. Comparisons between initial and final times assessed.

${ }^{b}$ Two-group mean comparison $t$ test. Comparisons between the mean differences across initial and final times assessed, in both groups.

In this setting, flaxseed is well known for its antioxidant, lipid and glycemic lowering actions [12] that have been attributed to its components linolenic acid, dietary fibers, lignans and its degradation products [13]. This study evaluates if flaxseed added to a weight loss diet generates improvement on nutritional and inflammatory markers.

\section{Methods}

\section{Ethics statement}

This study was approved by the Ethics Committee of Ribeirão Preto Medical School of São Paulo University (number 4244/2007) and conducted according to Declaration of Helsinki. All participants provided written informed consent. 


\section{Design of the study}

A prospective single blind and interventional study in which volunteers were divided into two groups, followed for 42 days and received similar proportions of carbohydrates plus brown flaxseed or rice raw powder. Participant recruitment and follow-up occurred between March 5th and July 25th, 2007.

\section{Participants and study settings}

Subjects were recruited from a large manufacturing company at the city of Itu, São Paulo, Brazil.

The inclusion criteria were male gender, age between 20-60 years-old and at least three of the following cardiovascular risk factors: waist circumference $\geq 90 \mathrm{~cm}$ [14]; Body Mass Index (BMI) $\geq 25 \mathrm{~kg} / \mathrm{m}^{2}$ [15]; fasting total cholesterol $\geq 200 \mathrm{mg} / \mathrm{dL}$, low density lipoprotein cholesterol (LDL-c) $\geq 130 \mathrm{mg} / \mathrm{dL}$, high density lipoprotein cholesterol $(\mathrm{HDL}-\mathrm{c})<40 \mathrm{mg} / \mathrm{dL}$, triglycerides $\geq 150$ $\mathrm{mg} / \mathrm{dL}$ [16]; glycemia $\geq 100 \mathrm{mg} / \mathrm{dL}$ [14]; systolic blood pressure $\geq 140 \mathrm{~mm} / \mathrm{Hg}$ and/or diastolic blood pressure $\geq$ $90 \mathrm{~mm} / \mathrm{Hg}$ [17]. The exclusion criteria were use of lipid lowering or weight loss medication in the last three months.

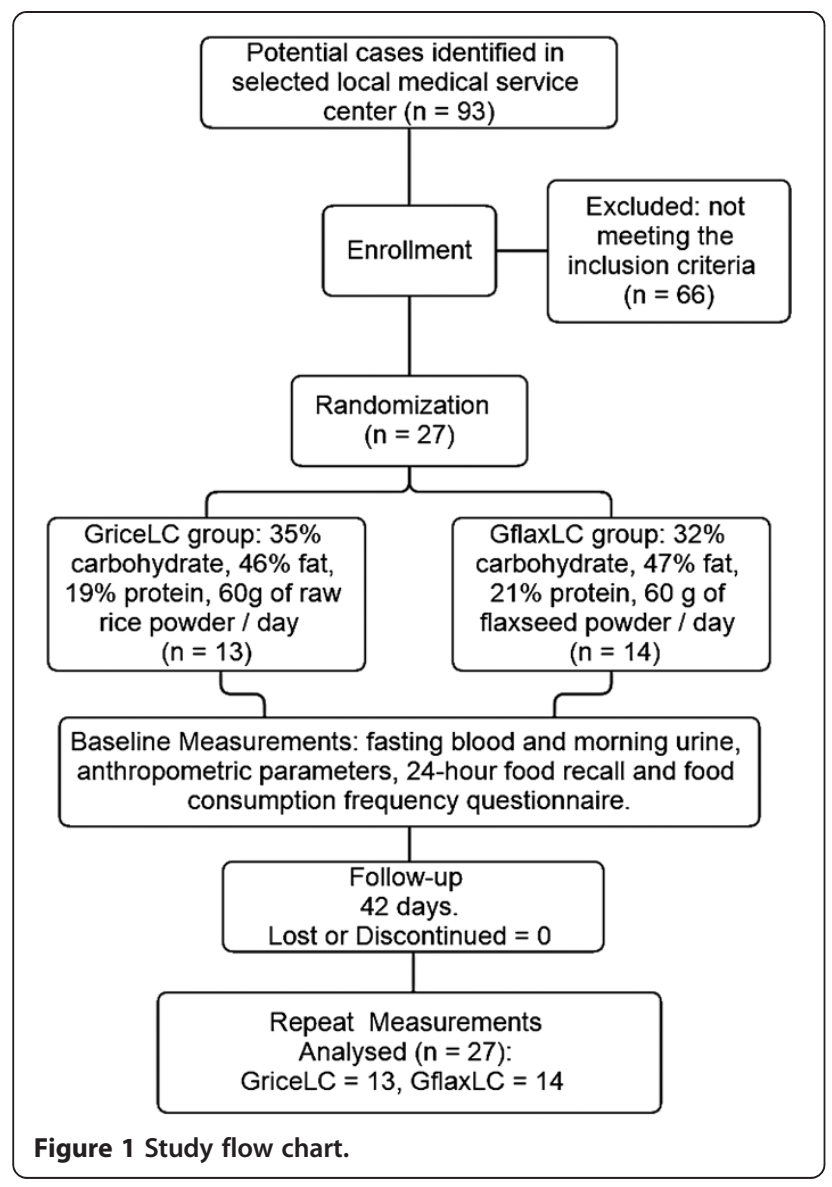

\section{Interventions}

Diet plans were provided to each group as following: $\mathrm{G}_{\text {riceLC }}$ group received 35\% carbohydrate, $46 \%$ fat, $19 \%$ protein and $60 \mathrm{~g}$ of raw rice powder/day. $\mathrm{G}_{\text {flaxLC }}$ group received $32 \%$ carbohydrate, $47 \%$ fat, $21 \%$ protein and $60 \mathrm{~g}$ of flaxseed powder/day. Table 1 shows the nutrient composition of diets.

Table 2 Blood pressure and anthropometric data, according to study group and time of assessment

\begin{tabular}{|c|c|c|c|}
\hline \multirow[b]{2}{*}{ Variable } & \multirow[b]{2}{*}{ Time } & \multicolumn{2}{|c|}{ Group } \\
\hline & & $\overline{G_{\text {ricelC }}(n=13)}$ & $G_{\text {flaxLC }}(n=14)$ \\
\hline \multirow[t]{3}{*}{ Systolic BP } & Initial & $134 \pm 9.2^{*}$ & $139 \pm 20.3^{*}$ \\
\hline & Final & $125 \pm 8.1$ & $127 \pm 17$ \\
\hline & $\begin{array}{l}\text { Mean } \\
\text { difference }\end{array}$ & $-9 \pm 12$ & $-12 \pm 11$ \\
\hline \multirow[t]{3}{*}{ Diastolic BP } & Initial & $80 \pm 7.7$ & $83 \pm 13.5$ \\
\hline & Final & $77 \pm 8.2$ & $81 \pm 8.9$ \\
\hline & $\begin{array}{l}\text { Mean } \\
\text { difference }\end{array}$ & $-3 \pm 10$ & $-2 \pm 11$ \\
\hline \multirow[t]{3}{*}{ Weight (Kg) } & Initial & $94,9 \pm 11,2^{*}$ & $96 \pm 14^{*}$ \\
\hline & Final & $88,1 \pm 10,2$ & $90 \pm 14$ \\
\hline & $\begin{array}{l}\text { Mean } \\
\text { difference }\end{array}$ & $-7 \pm 2$ & $-6 \pm 6$ \\
\hline \multirow[t]{3}{*}{ BMI $\left(\mathrm{kg} / \mathrm{m}^{2}\right)$} & Initial & $32,1 \pm 2,8^{*}$ & $32 \pm 3^{*}$ \\
\hline & Final & $29,8 \pm 2,5$ & $30 \pm 4$ \\
\hline & $\begin{array}{l}\text { Mean } \\
\text { difference }\end{array}$ & $-2.3 \pm 0.7$ & $-1.9 \pm 2$ \\
\hline \multirow[t]{3}{*}{ Waist circumference (cm) } & Initial & $107 \pm 8^{*}$ & $108 \pm 8^{*}$ \\
\hline & Final & $93 \pm 6$ & $95 \pm 8$ \\
\hline & $\begin{array}{l}\text { Mean } \\
\text { difference }\end{array}$ & $-14 \pm 3$ & $-13 \pm 4$ \\
\hline \multirow[t]{3}{*}{ Hip circumference $(\mathrm{cm})$} & Initial & $108 \pm 7^{*}$ & $106 \pm 8^{*}$ \\
\hline & Final & $104 \pm 6$ & $103 \pm 7$ \\
\hline & $\begin{array}{l}\text { Mean } \\
\text { difference }\end{array}$ & $-4 \pm 2$ & $-2 \pm 2^{* b}$ \\
\hline \multirow[t]{3}{*}{ Subscapular. skinfold (mm) } & Initial & $41 \pm 13^{*}$ & $38 \pm 11^{*}$ \\
\hline & Final & $18 \pm 3$ & $20 \pm 5$ \\
\hline & $\begin{array}{l}\text { Mean } \\
\text { difference }\end{array}$ & $-23 \pm 11$ & $-18 \pm 7$ \\
\hline \multirow[t]{3}{*}{ Supra iliac skinfold (mm) } & Initial & $33 \pm 12^{*}$ & $37 \pm 9^{*}$ \\
\hline & Final & $15,2 \pm 4$ & $16 \pm 4$ \\
\hline & $\begin{array}{l}\text { Mean } \\
\text { difference }\end{array}$ & $-17 \pm 8$ & $-21 \pm 10$ \\
\hline \multirow[t]{3}{*}{ Abdominal skinfold (mm) } & Initial & $65 \pm 5^{*}$ & $66 \pm 3^{*}$ \\
\hline & Final & $23 \pm 4$ & $25 \pm 5$ \\
\hline & $\begin{array}{l}\text { Mean } \\
\text { difference }\end{array}$ & $-42 \pm 4$ & $-40 \pm 6$ \\
\hline
\end{tabular}

Data are expressed in mean \pm Standard Deviation. $n$, number of subjects; $B P$, blood pressure $(\mathrm{mmHg})$; BMl, body mass index, $\mathrm{kg} / \mathrm{m}^{2}$, kilogram per meter squared. *Significant difference between initial and final times $(p<0.05)$. ${ }^{b}$ Two-group mean comparison $t$ test. Comparisons between the mean differences across initial and final times assessed, in both groups. 
Table 3 Fasting biochemical data, according to study group and time of assessment

\begin{tabular}{|c|c|c|c|}
\hline \multirow[t]{2}{*}{ Variable } & \multirow[t]{2}{*}{ Time } & \multicolumn{2}{|c|}{ Group } \\
\hline & & $G_{\text {ricelC }}(n=13)$ & $G_{\text {flaxLC }}(n=14)$ \\
\hline \multirow[t]{3}{*}{ Glycemia (mg/dL) } & Initial & $98 \pm 16$ & $90 \pm 15$ \\
\hline & Final & $91 \pm 12$ & $88 \pm 10$ \\
\hline & $\begin{array}{l}\text { Mean } \\
\text { difference }\end{array}$ & $-7 \pm 13$ & $-1 \pm 16$ \\
\hline \multirow[t]{3}{*}{ Total cholesterol (mg/dL) } & Initial & $205 \pm 36^{*}$ & $223 \pm 50^{*}$ \\
\hline & Final & $180 \pm 31$ & $186 \pm 41$ \\
\hline & $\begin{array}{l}\text { Mean } \\
\text { difference }\end{array}$ & $-25 \pm 21$ & $-37 \pm 37$ \\
\hline \multirow[t]{3}{*}{ LDL-c (mg/dL) } & Initial & $135 \pm 50^{*}$ & $151 \pm 59^{*}$ \\
\hline & Final & $110 \pm 26$ & $116 \pm 37$ \\
\hline & $\begin{array}{l}\text { Mean } \\
\text { difference }\end{array}$ & $-25 \pm 39$ & $-31 \pm 51$ \\
\hline \multirow[t]{3}{*}{$\mathrm{HDL}-\mathrm{c}(\mathrm{mg} / \mathrm{dL})$} & Initial & $44 \pm 9$ & $42 \pm 5^{*}$ \\
\hline & Final & $42 \pm 7$ & $38 \pm 4$ \\
\hline & $\begin{array}{l}\text { Mean } \\
\text { difference }\end{array}$ & $-2 \pm 6$ & $-4 \pm 5$ \\
\hline \multirow[t]{3}{*}{ Triacylglycerol $^{(\&)}(\mathrm{mg} / \mathrm{dL})$} & Initial & $241 \pm 264$ & $215 \pm 110^{*}$ \\
\hline & Final & $144 \pm 56$ & $153 \pm 83$ \\
\hline & $\begin{array}{l}\text { Mean } \\
\text { difference }\end{array}$ & $-97 \pm 252$ & $-62 \pm 71$ \\
\hline \multirow[t]{3}{*}{ Uric acid (mg/dL) } & Initial & $7 \pm 1^{*}$ & $7 \pm 2^{*}$ \\
\hline & Final & $6 \pm 1$ & $6 \pm 3$ \\
\hline & $\begin{array}{l}\text { Mean } \\
\text { difference }\end{array}$ & $-0.5 \pm 0.7$ & $-0.7 \pm 0.8$ \\
\hline \multirow[t]{3}{*}{ Insulin ${ }^{(\&)}$ (micro IU/mL) } & Initial & $18 \pm 14^{*}$ & $12 \pm 8$ \\
\hline & Final & $7 \pm 5$ & $9 \pm 5$ \\
\hline & $\begin{array}{l}\text { Mean } \\
\text { difference }\end{array}$ & $-11 \pm 13$ & $-3 \pm 8$ \\
\hline \multirow[t]{3}{*}{ HOMA beta ${ }^{(\&)}$} & Initial & $60 \pm 40^{*}$ & $49 \pm 55$ \\
\hline & Final & $25 \pm 16$ & $31 \pm 18$ \\
\hline & $\begin{array}{l}\text { Mean } \\
\text { difference }\end{array}$ & $-35 \pm 40$ & $-18 \pm 54$ \\
\hline \multirow[t]{3}{*}{ HOMA IR ${ }^{(\&)}$} & Initial & $5 \pm 5^{*}$ & $3 \pm 1$ \\
\hline & Final & $2 \pm 1$ & $2 \pm 1$ \\
\hline & $\begin{array}{l}\text { Mean } \\
\text { difference }\end{array}$ & $-3 \pm 4$ & $-1 \pm 1$ \\
\hline
\end{tabular}

Data are expressed in mean \pm Standard Deviation. $n$, number of subjects; HOMA-IR, homeostasis model assessment of insulin resistance; LDL-C, low-density lipoprotein cholesterol; HDL-c, high-density lipoprotein cholesterol. *Significant difference between initial and final times $(p<0.05)$

\& Variable analyzed with log transformation.

Flaxseed and raw rice were crushed weekly by minimal particle type mill. Also, sieves were used for optimal grinding grain with a size of $250 \mathrm{~mm} / \mathrm{micrometers}$

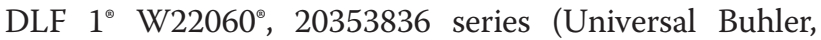
$\mathrm{CMBH}$, Germany) and Vibrating $\mathrm{MAQ}^{\circ}$ model 2221, 10.04 series $\left(\right.$ Bertel $^{\oplus}$ Brazil). After crushing flaxseed and raw rice, they were weighed in a semi-analytical scale, $\mathrm{OHAUS}^{\ominus}$ (Germany) and packed in suitable plastic bags.

The following meals were made at the company: breakfast, light meal, lunch and afternoon snack. Dinner, evening snack and weekend meals were performed at home. The addition of flaxseed or raw rice powder was made in the light meal (40 g added to milk) and lunch (20 $\mathrm{g}$ added to baked beans). Regarding to blinding method, only a research member who did not have access to data knew what each volunteer received, rice or flaxseed.

\section{Dietary assessment}

Dietary intake was assessed twice by 24-hour food recall, in a week day and in a weekend day. Nutrient composition of the diets at baseline and during the nutritional intervention was performed using the Diet $\mathrm{PRO}^{\circ}$ Program, version 4 (Agromídia Based Technology Company ${ }^{\oplus}$, Viçosa, Brazil, MG).

\section{Physical examination}

Height and weight were measured according to institutional protocols [18]. BMI was classified as suggested by World Health Organization (WHO) [15]. Suprailiac, subscapular and abdominal skinfolds were evaluated using a compass Lange ${ }^{\odot}$ (Beta Technology Incorporated, USA). Waist and hip circumferences were also analyzed [19]. Blood pressure was measured by an automated device $\left(\mathrm{OMRON}^{\circ}\right.$ HEM 705-CP, Japan) following current guidelines [20].

\section{Biochemical assessments}

Blood was collected after 12-hour fasting for biochemical assessments: total cholesterol and fractions (LDL-c and HDL-c), triglycerides, glucose, insulin, homeostasis model assessment for $\beta$-cell function (HOMA- $\beta$ ) and insulin resistance (HOMA-IR), uric acid, as well as for evaluation of inflammatory markers (CRP, TNF- $\alpha$ ), serum isoprostane and hormones (leptin and adiponectin).

Determination of total cholesterol, HDL-c, triglyceride, glucose and uric acid was performed by enzymatic method, with HITACHI $^{\oplus} 912$ - ROCHE (Japan). Reagents used were: CHOD-PAP, ROCHE (Japan) for total cholesterol and triglyceride; Bioclin K071 (Japan) for HDL-c; GOD-PAD (Roche) (Japan) for glucose and Uric Acid Plus (URICASE) (Japan) for uric acid. Friedewald equation was used to determine LDL-c [21].

IMMULITE $1000^{\circ}$ SYSTEMS - Siemens Medical Solutions Diagnostics (Los Angeles, USA) was used to detect insulin by chemiluminescence. HOMA indexes were obtained by equations disclosed in literature [22].

Immunoturbidimetric assay was performed with the COBAS $^{\oplus}$ MIRAPLUS - ROCHE (USA) with $0.03 \mathrm{mg} / \mathrm{L}$ as detection limit and intra assay coefficient of variation 
of $10 \%$ to measure ultra-sensitive CRP. The reagent used was TURB-PCR, manufacturer ERBRAM Prods. Laboratory Ltda. (São Paulo, Brazil). TNF- $\alpha$, leptin and adiponectin were measured by enzyme immunoassay method, using LINCOPLEX-LUMINEX ${ }^{\circ}$ kits, Millipore Corporation (USA). Determination of 8-IsoProstaglandin F2a (serum isoprostane) was performed by enzyme immunoassay kits, ASSAY DESIGNS ${ }^{\bullet}$ Inc, (USA).

Serum and urinary enterolignans, enterodiol (END) and enterolactone (ENL) were assessed by high performance liquid chromatography with Shimadzu model LC $10 \mathrm{AD}^{\circ}$ (Shimadzu Corporation, Japan).

\section{Statistical methods}

Student's t-test for paired data was used for comparisons between initial (day zero) and final (day 42) assessments. The mean differences between final and initial times of data collection in both groups were compared by two-group mean comparison test ( $t$ test) or Wilcoxon rank-sum test when appropriate. When assumption of normality of data was rejected, variable was normalized after logarithmic transformation or non-parametric tests were used. The analyses were conducted with STATA/IC, version 11.2 (StataCorp LP, USA). The significance level used for the tests was $5 \%$.

\section{Results}

Participant flow and baseline characteristics

The selection flow of subjects was summarized in Figure 1. From 93 employees evaluated, 27 were allocated as follow: 13 in $G_{\text {ricelC }}$ and 14 in $G_{\text {flaxLC}}$. The mean age was $33 \pm 10$ years to $G_{\text {riceLC }}$ and $40 \pm 9$ years to $G_{\text {flaxLC. The baseline }}$ clinical, biochemical and dietary characteristics are shown in Tables 1, 2 and 3 in the time frame marked as initial. Both groups showed a reduction of approximately $56 \%$ of energy intake compared to baseline.

\section{Blood pressure, anthropometric and biochemical data}

Both groups had their anthropometric and systolic blood pressure measurements reduced (Table 2). Hip circumference reduction was greater in $G_{\text {ricelC }}$ group. Weight loss achieved by $G_{\text {riceLC }}$ and $G_{\text {flaxLC }}$ were $7 \pm 2$ and $6 \pm 6$ $\mathrm{kg}$ (mean $\pm S D)$, respectively. $G_{\text {ricelC }}$ and $G_{\text {flaxLC }}$ had their levels of total cholesterol, LDL cholesterol and uric acid decreased (Table 3). $\mathrm{G}_{\text {flaxLC }}$ increased blood levels of END and ENL, as well as urinary levels of ENL. On the other hand, $G_{\text {ricelC }}$ reduced blood levels of END and urinary levels of ENL (Figure 2).

\section{Inflammatory markers and hormones}

Figure 3 illustrates the changes in inflammatory and hormonal markers according to study group and assessment time. Levels of CRP and TNF- $\alpha$ were reduced $(p<0.05)$ only in $\mathrm{G}_{\text {flaxLC }}$ (mean decrease of $25 \%$ and $46 \%$ respectively)

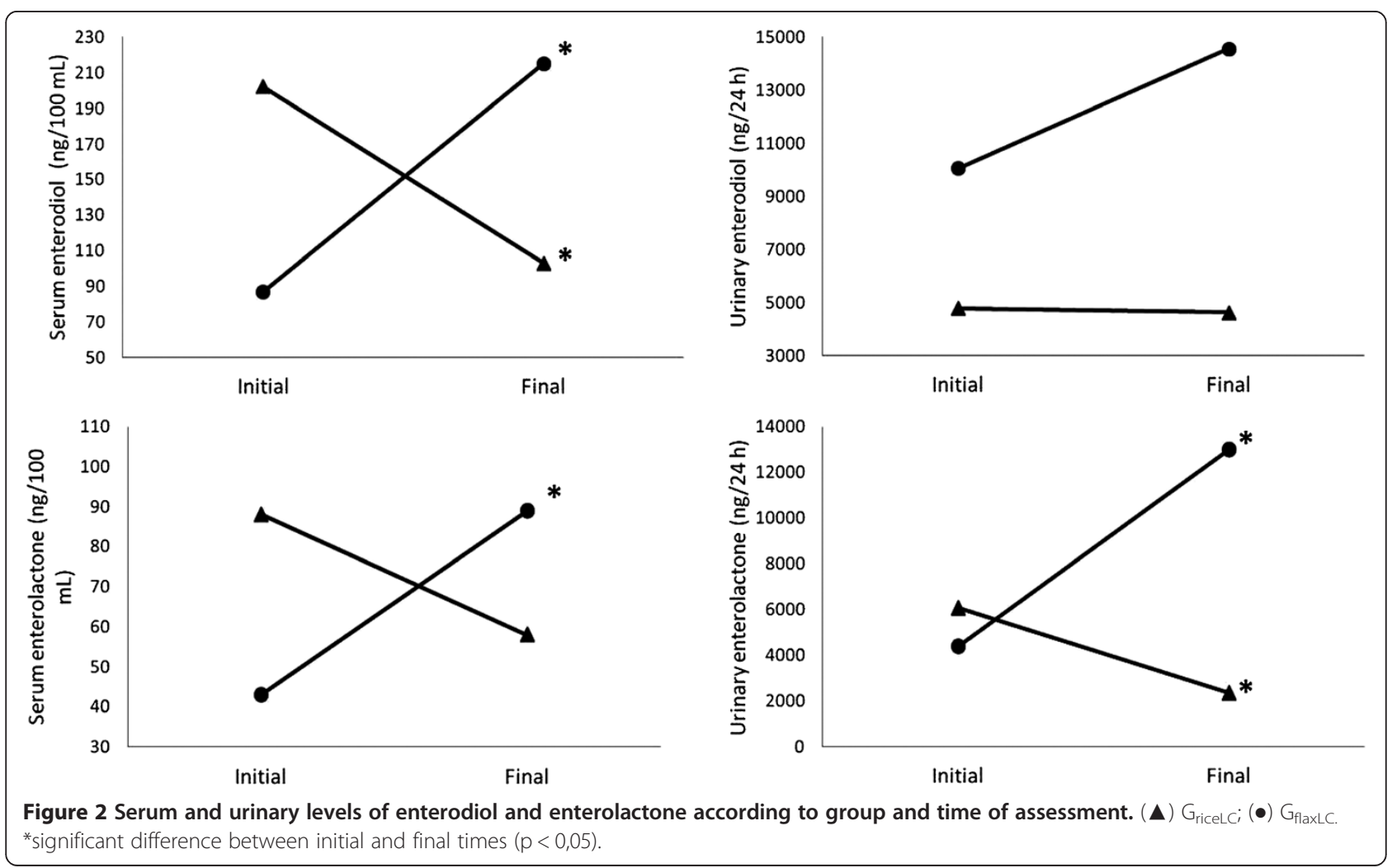




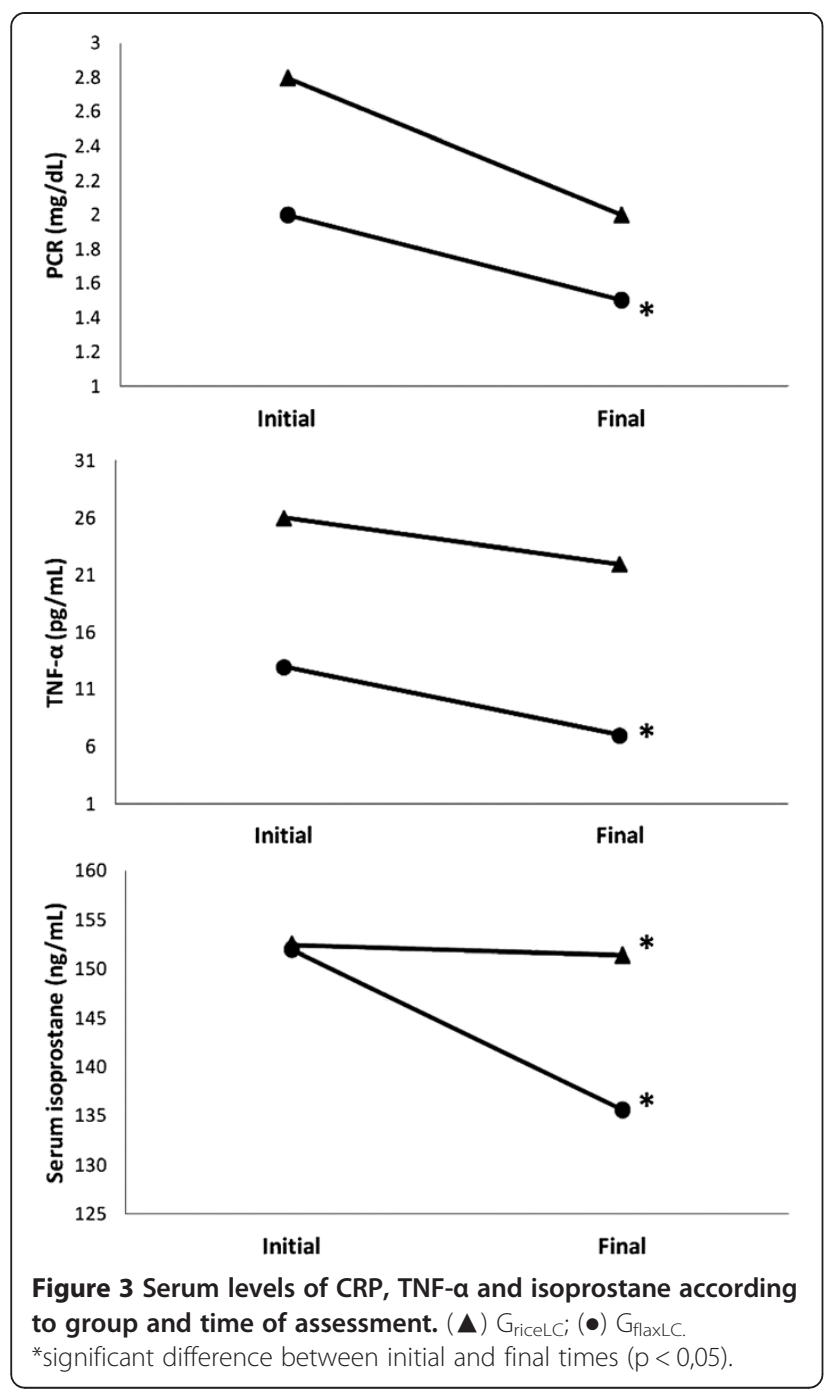

and isoprostane was reduced in both groups. Also, both groups increased levels of adiponectin (Figure 4).

\section{Discussion}

This study shows a decrease in inflammatory markers (CRP and TNF- $\alpha$ ) only in group who received flaxseed, allowing the assumption yet described in literature that anti-inflammatory and antiatherogenic activities could be attributed to components of flaxseed, such as lignans and its derivatives [23]. Pan et al. showed that dietary supplementation with capsules of lignans from flaxseed (360 mg/d) for 12 weeks modulates CRP levels in type II diabetics when compared to placebo group [24]. The mechanisms behind these effects could be that glycosides of lignans found in flaxseed are hydrolyzed by colon bacteria producing bioactive lignans such as enterolactone (ENL) and enterodiol (END) [25]. These substances were found to protect against cardiovascular disease by decreasing inflammatory response [24,26].

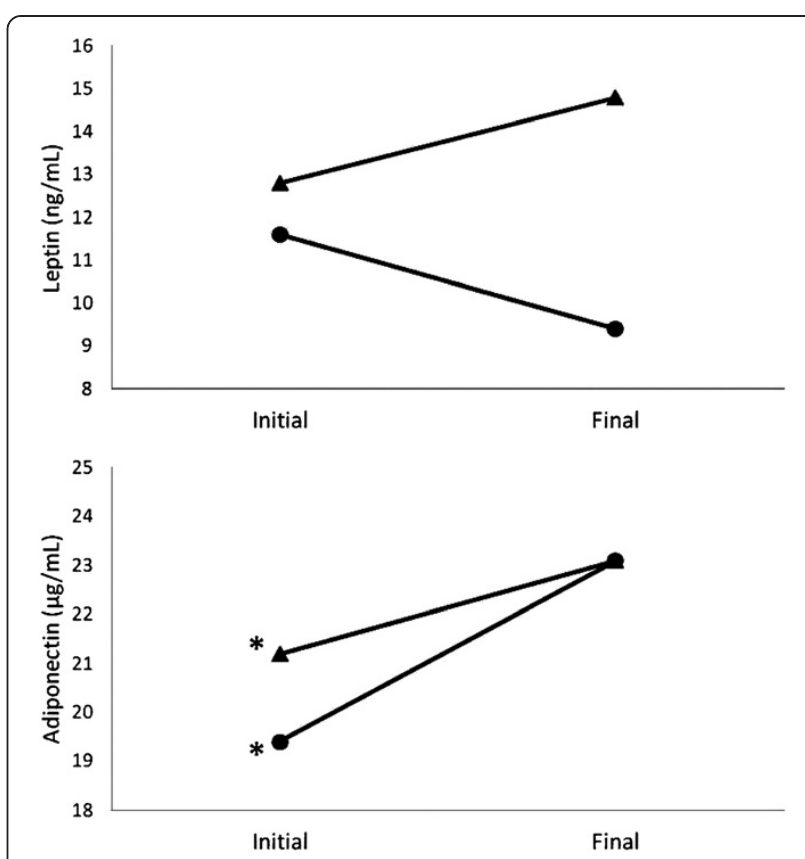

Figure 4 Leptin and adiponectin levels according to group and time of assessment. ( $\mathbf{\Delta}) \mathrm{G}_{\text {ricelci }}(\bullet) G_{\text {flaxLC. }}{ }^{*}$ significant difference between initial and final times $(p<0,05)$.

Increases in blood and urinary levels of END and ENL in the present study indicate absorption of lignans (Figure 2). Also, antioxidant properties of lignans not evaluated in our study, like reactive oxygen species scavenger, as well as prevention of lipid peroxidation in liver could be beneficial on human health $[6,27]$.

Inflammation and elevated pro-inflammatory adipokines, such as TNF- $\alpha$ induced by activation of nuclear factor kappa B, are also associated with excess weight, especially with increased visceral fat $[28,29]$. Correlations have been observed between increased TNF- $\alpha$ and decreased anti-inflammatory adipokines, known as adiponectin. These interrelations contribute to long-term complications such as insulin resistance, endothelial dysfunction and atherosclerosis [30]. In this trial, both groups increased adiponectin blood levels suggesting that protection from diseases could be reached by weight loss in patients with overweight and obesity.

Both groups achieved weight loss and reduction of waist circumference, as well as other anthropometric data (Table 2), explained by lower energy intake (Table 1) [31]. In this matter, we strengthened that to lose weight, the total intake and negative energy balance is more important than diet composition itself $[7,12]$. Moreover, reduction of blood pressure was another positive impact on health observed in both groups, which can be explained by improvements on weight and central adiposity $[32,33]$. 
Other variables, such as total cholesterol, LDL-c and uric acid also improved in groups $G_{\text {ricelC }}$ and $G_{\text {flaxLC }}$. Reducing carbohydrate intake has been related to ameliorated biochemical and hormonal profiles, regardless weight loss [34,35]. On the other hand, some of these benefits could be explained by addition of flaxseed, since some studies have suggested that it reduces hypercholesterolemia, hyperinsulinemia, hyperleptinemia as well as accumulation of visceral fat, specifically in the liver [6].

Serum triglycerides levels only decreased in $\mathrm{G}_{\text {flaxLC. }}$. A study with hypercholesterolemic rabbits that consumed crushed flaxseed also showed reduced serum levels of LDL-c and triglycerides [36]. $G_{\text {flaxLC }}$ received greater amounts of Omega-3 (Table 1) than $G_{\text {riceLC }}(14 \pm 2$ versus $3 \pm 2 \mathrm{~g} /$ day, $\mathrm{p}<0.01)$ which suggests that flaxseed omega 3 fatty acids really contributes to triglyceride reduction. In the past, its been suggested that very high amounts of flaxseed oil, rich in omega 3 , would be able to reduce the triglyceridemia in the same way as fish oil omega 3 [37]. However, recent reviews did not find any advantage using flaxseed oil compared to fish oils, as well as another vegetal oil, in this case, olive [38,39]. One explanation for the absence of evidence of the effect of flaxseed oil in recent papers is that omega-3 fatty acids from vegetable oils is alpha-linolenic acid (ALA), different from fish oils that have, for example, the promoters of effects, eicosapentaenoic acid (EPA) and docosahexaenoic acid (DHA). ALA can be converted into EPA and DHA by the human body, but only in small fractions $(5 \%)$, which is why we recommend the consumption of omega-3 from animal origin [40,41]. Finally, we can not conclude that in our study, the reduction of triglycerides in $G_{\text {flaxLC }}$ was due to flaxseed, weight loss or reduction of carbohydrates, since due to the small size of sample, statistical significance in $G_{\text {ricelC }}$ was not achieved. Both groups showed significant reduction in serum isoprostane. Decrease of this biomarker of lipid peroxidation occurred in the presence of nutritional intervention, being essential calorie reduction, consumption of fibers, decrease in body weight and in central adiposity [42]. This trial has some limitations including convenience sampling with a small number of subjects allocated in each group. Therefore, it is not possible warrant if the outcomes were related to weight loss, intake of carbohydrates or flaxseed or a combination of these interventions.

\section{Conclusion}

Despite limitations, this study suggests that in the evaluated population, weight loss diet could be an important strategy to reduce inflammation markers such as CRP and TNF- $\alpha$. Also, flaxseed could contribute to this outcome. Moreover, reductions observed in blood pressure and central adiposity could additionally protect against cardiovascular diseases.

\section{Availability of supporting data}

The data set supporting the results of this article is available as six additional material files (.xls) Additional files $1,2,3,4,5$ and 6.

\section{Additional files}

Additional file 1: Biochemical Data: measurements of lipidic profile, uric acid, blood glucose, insulin and CRP.

Additional file 2: Anthropometric Data: weight, BMI and other anthropometric measurements.

Additional file 3: Blood pressure Data.

Additional file 4: TNF, adiponectin, leptin and isoprostane.

Additional file 5: Blood and urinary levels of lignans.

Additional file 6: Nutritional composition of diet.

\section{Abbreviations}

CRP: Protein C Reactive; TNF-a: Tumor Necrosis Factor Alpha; BMI: Body Mass Index; LDL-c: Low density lipoprotein cholesterol; HDL-c: High density lipoprotein cholesterol; HOMA- $\beta$ : Homeostasis model assessment for $\beta$-cell function; HOMA-IR: Insulin resistance; END: Enterodiol; ENL: Enterolactone; ALA: Alpha-linolenic acid; EPA: Eicosapentaenoic acid; DHA: Docosahexaenoic acid.

\section{Competing interests}

The authors declare that they have no competing interests.

\section{Authors' contributions}

Designed the experiments: RSLC and JSM. Conducted the research: RSLC. Analyzed the data and wrote the paper: RSLC, PGF, JHS and JSM. Reviewed the paper: RSLC, PGF, JHS, CMML and JSM. JSM had primary responsibility for the final content. All the authors read and approved the final manuscript.

\section{Authors' information}

JSM is full professor of Division of Medical Nutrition at University of São Paulo.

\section{Acknowledgments}

This study was partially financed by CNPq grant (304127/2009-4) intended to JSM and also by FAEPA - Fundação de Apoio ao Ensino, Pesquisa e Assistência do Hospital das Clínicas da Faculdade de Medicina de Ribeirão Preto/University of São Paulo. PGF, JHS and CMML received scholarships 2012/22543-3, 2012/21579-4 and 2012/21626-2, respectively from FAPESP Fundação de Amparo à Pesquisa de São Paulo. CNPq, FAEPA and FAPESP are government agencies that provide financial resources, but generated no influences in the study.

\section{Author details}

${ }^{1}$ Institute of Nutrition. Itu, São Paulo, Brazil. ²Department of Medicine, Division of Medical Nutrition, Ribeirão Preto Medical School, University of São Paulo, Avenida Bandeirantes, 3900 Bairro Monte Alegre, CEP: 14049-900, Ribeirão Preto, São Paulo, Brazil.

Received: 9 September 2014 Accepted: 29 December 2014 Published: 10 January 2015

\section{References}

1. Hansson GK. Immune mechanisms in atherosclerosis. Arterioscl Throm Vas. 2001;21:1876-90.

2. Couillard C, Ruel G, Archer WR, Pomerleau S, Bergeron J, Couture P, et al. Circulating levels of oxidative stress markers and endothelial adhesion molecules in men with abdominal obesity. J Clin Endocr Metab. 2005;90:6454-9. 
3. Paschos G, Zampelas A, Panagiotakos DB, Katsiougiannis S, Griffin B, Votteas $V$, et al. Effects of flaxseed oil supplementation on plasma adiponectin levels in dyslipidemic men. Eur J Nutr. 2007;46:315-20.

4. Shoelson SE, LEE J, Goldfine AB. Inflammation and insulin resistance. J Clin Invest. 2006;1 16:1793-801.

5. Fantuzzi G, Mazzone T. Adipose tissue and atherosclerosis. Exploring the connection. Arterioscl Throm Vas. 2007;27:996-1003.

6. Fukumitsu S, Aida K, Ueno N, Ozawa S, Takahashi Y, Kobori M. Flaxseed lignan attenuates high fat diet induced fat accumulation and induces adiponectin expression in mice. Brit J Nutr. 2008;100:669-76.

7. Jensen MD, Ryan DH, Apovian CM, Ard JD, Comuzzie AG, Donato KA, et al. 2013 AHA/ACC/TOS guideline for the management of overweight and obesity in adults: a report of the American college of cardiology/American heart association task force on practice guidelines and the obesity society. Circulation. 2014;129(25 Suppl 2):S102-38.

8. Matarese LE, Pories WJ. Adult weight loss diets: metabolic effects and outcomes. Nutr Clin Pract. 2014;29:759-67.

9. Esmaillzadeh A, Mirmiran P, Azizi F. Whole grain intake and the prevalence of hypertriglyceridemic waist phenotype in tehranian adults. Am J Clin Nutr. 2005;81:55-63.

10. Esmaillzadeh A, Kimiagar M, Mehrabi Y, Azadbakht L, Hu FB, Willett WC. Fruit and vegetable intakes, $\mathrm{C}$-reactive protein, and the metabolic syndrome. Am J Clin Nutr. 2006;84:1489-97.

11. Lemieux I, Pascot A, Prud'homme D, Alméras N, Bogaty P, Nadeau A, et al. Elevated C-reactive protein. Another component of the aterosthrombotic profile of abdominal obesity. Arterioscl Throm Vas. 2001;21:961-7.

12. Kris-etherton PM, Harris WS, Appel LJ. Fish consumption, fish oil, omega-3 fatty acids, and cardiovascular disease. Circulation. 2002;106:2747-57.

13. Bloendon LT, Balikai S, Chittams J, Cunnane SC, Berlin JA, Rader DJ, et al. Flaxseed and cardiovascular risk factors: results from a double blind, randomized, controlled clinical trial. J Am Coll Nutr. 2008;27:65-74.

14. IDF. International Diabetes Federation: The IDF Consensus Worldwide Definition of the Metabolic Syndrome.

15. WHO. Obesity: Presenting and Managing the Goal Epidemic. Report of a WHO Consulation on Obesity. Geneva: World Health Organization; 1998.

16. Expert Panel on Detection, Evaluation, and Treatment of High Blood Cholesterol in Adults. Executive summary of the third report of the national cholesterol education program (NCEP) expert panel on detection, evaluation, and treatment of high blood cholesterol in adults (adult treatment panel III). JAMA. 2001;285:2486-97.

17. Chobanian AV, Bakris GL, Black HR, Cushman WC, Green LA, Izzo JL, et al. Seventh report of the joint national committee on: prevention, detection, evaluation, and treatment of high blood pressure. Hypertension. 2003:42:1206-52

18. Nicoletti CF, Camelo Jr JS, dos Santos JE, Marchini JS, Salgado Jr W, Nonino CB. Bioelectrical impedance vector analysis in obese women before and after bariatric surgery: changes in body composition. Nutrition. 2014;30:569-74.

19. NHANES III. National Health and Nutrition Examination Survey. National Center for Health Statistics; 2009. Available: http://www.cdc.gov/nchs/data/ nhanes/nhanes_01_02/body_measures_year_3.pdf. Accessed 02 June.

20. Mion Jr D, Gomes MAM, Nobre F, Amodeo C, Kohlmann Jr O, Praxedes JN, et al. IV Brazilian guidelines on hypertension. Arq Bra Cardiol. 2004;82(2):15-22.

21. Friedewald WT, Levy RI, Fredrickson DS. Estimation of the concentration of low-density lipoprotein cholesterol in plasma, without use of the preparative ultracentrifuge. Clin Chem. 1972;18:499-502.

22. Vasques ACJ. Análise crítica do uso dos índices do homa na avaliação da rersistencia à insulina e capacidade funcional das celulas $-\beta$ panceráticas. Arq Bras Endocrinol. 2008;2:52-61.

23. Hallund J, Tetens I, Bugel S, Tholstrup T, Bruun JM. The effect of a lignan complex isolated from flaxseed on inflammation markers in healthy postmenopausal women. Nutr Metab Cardiovas. 2008;18:497-502.

24. Pan $A$, Wahnefried WD, Xingwang $Y, Y u Z$, Li H, Qi Q, et al. Effects of a flaxseed derived lignan supplement on C-reactive protein, IL-6 and retinol binding protein 4 in type 2 diabetic patients. Brit J Nutr. 2008;74:1-5.

25. Prasad K. Hypocholesterolemic and antiatherosclerotic effect of flax lignan complex isolated from flaxseed. Atherosclerosis. 2005;179:269-75.

26. Arts ICW, Hollman PCH. Polyphenols and disease risk in epidemiologic studies. Am J Clin Nutr. 2005:81:317S-25S.

27. Kivelã AM, Kansanen E, Jyrkkânen HK, Nurmi T, Ylã-herttuala S, Levonen AL. Enterolactone induces heme oxygenase- 1 expression trough nuclear factor E2 related factor 2 activation in endothelial cells. J Nutr. 2008;138:1263-8.
28. Dandona P, Aljada A, Bandyopadhyay A. Inflammation: the link between insulin resistance, obesity and diabetes. Trends Immunol. 2004:25:4-7.

29. Radulian G, Rusu E, Dragomir AD, Posea M. Metabolic effects of low glycaemic index diets. Nutr J. 2009;8:1-8.

30. Madsen EL, Rissanen A, Bruun JM, Skogstrand K, Tonstad S, Hougaard DM, et al. Weight loss larger than $10 \%$ is neede for general improvement of levels of circulation adiponectin and markers of inflammation in obese subjects: a 3-year weight loss study. Euro J Endocrinol. 2008;158:179-87.

31. Redman LM, Heilbronn LK, Martin CK, Jonge L, Williamson DA, Delany JP, et al. Metabolic and behavioral compensations in response to caloric restriction: Implications for the maintenance of weight loss. PLoS One. 2009;:4:e4377.

32. Guimarães ICB, de Almeida $A$, Santos $A S$, Barbosa DBV, Guimarães $A C$. Pressão arterial: efeito do índice de massa corporal e da circunferência abdominal em adolescentes. Arq Bras Cardiol. 2008;90:426-32.

33. Stevens VJ, Obarzanek E, Cook NR, Lee IM, Appel L, Smith West D, et al. Long-term weight loss and changes in blood pressure: results of the trials of hypertension prevention, phase II. Ann Intern Med. 2001;134:1-11.

34. Pan A, Sun J, Chen Y, Ye X, Li H, Yu Z, et al. Effects of a flaxseed-derived lignan supplement in type 2 diabetic patients: a randomized, double-blind, cross-over trial. PLoS One. 2007;2:e1148.

35. Bassett CM, Rodriguez-Leyva D, Pierce GN. Experimental and clinical research findings on the cardiovascular benefits of consuming flaxseed. Appl Physiol Nutr Me. 2009;34:965-74.

36. Prim CR, Baroncini LAV, Précoma LB, Caron PHL, Winter G, Poletti MO, et al. Effects of linseed consumption for a short period of time on lipid profile and atherosclerotic lesions in rabbits fed a hypercholesterolaemic diet. Brit J Nutr. 2012;107:660-4.

37. Harris WS. n-3 fatty acids and serum lipoproteins: human studies. Am J Clin Nutr. 1997;65:1645S-54S.

38. Kontogianni MD, Vlassopoulos A, Gatzieva A, Farmaki AE, Katsiougiannis S, Panagiotakos DB, et al. Flaxseed oil does not affect inflamatory markes and lipid profile compared to olive, in young, healthy, normal weight adults. Metabolism. 2013;62:686-93.

39. Balk EM, Lichtenstein AH, Chung M, Kupelnick B, Chew P, Lau J. Effects of omega-3 fatty acids on serum markers of cardiovascular disease risk: a systematic review. Atherosclerosis. 2006;189:19-30.

40. Jump DB, Depner CM, Tripathy S. Omega-3 fatty acid supplementation and cardiovascular disease. J Lipid Res. 2012;53:2525-45.

41. Santos RD, Gagliardi ACM, Xavier HT, Magnoni CD, Cassani R, Lottenberg AM. Sociedade brasileira de cardiologia. I diretriz sobre o consumo de gorduras e saúde cardiovascular. Arq Bras Cardiol. 2013;100:1-40.

42. Vanharanta M, Voutilainen S, Nurmi T, Kaikkonen J, Roberts LJ, Morrow JD, et al. Association between low serum enterolactone and increased plasma f2-isoprostanes, a measure of lipid peroxidation. Atherosclerosis. 2002;160:465-9.

doi:10.1186/1475-2891-14-5

Cite this article as: Cassani et al:: Impact of weight loss diet associated with flaxseed on inflammatory markers in men with cardiovascular risk factors: a clinical study. Nutrition Journal 2015 14:5.

\section{Submit your next manuscript to BioMed Central and take full advantage of:}

- Convenient online submission

- Thorough peer review

- No space constraints or color figure charges

- Immediate publication on acceptance

- Inclusion in PubMed, CAS, Scopus and Google Scholar

- Research which is freely available for redistribution 